\title{
Correspondence
}

http://dx.doi.org/10.11646/phytotaxa.167.1.10

\section{Taxonomic re-evaluation of the enigmatic Pyrus magyarica (Rosaceae)}

\author{
ZOLTÁN BARINA ${ }^{1}$ \& GERGELY KIRÁLY ${ }^{2}$ \\ ${ }^{1}$ Hungarian Natural History Museum, 1476 Budapest, Pf. 222; barina@bot.nhmus.hu \\ ${ }^{2}$ University of West Hungary, 9400 Sopron, Ady E. u. 5; kbgergely@gmail.com
}

\begin{abstract}
Pyrus magyarica was considered as a "superendemic" species of the Carpathian Basin for a long time; however, despite its presumed significance, doubts about its taxonomical status have been raised. The confusions originate from the invalidity of the description and the lack of type material. Latter interpretations are not consistent and contradict the description of the species in the protologue. The authors attempted to get access to the original material of the taxon, but no vouchers or living specimens that correspond to the protologue were found; herbarium specimens assigned as $P$. magyarica mostly refer to $P$. pyraster. Based on the available records, $P$. magyarica cannot be clearly defined and re-described; thus we propose to leave off the use of the name P. magyarica as it has no clear content.
\end{abstract}

Key words: invalid description, typification, endemism, Carpathian Basin, Pyrus

\section{Introduction}

Pyrus magyarica Terpó (1960: 34) was described as an endemic and relict species of the Carpathian Basin; it was assessed in major European syntheses (Terpó \& Amaral 1968, Kurtto et al. 2013) also at species rank. Due to its singularity, P. magyarica was denoted as a priority species in Annex II of the EU Habitats Directive and treated as a critically endangered species in Europe (Bilz et al. 2011).

The taxon was described from Hungary, and it was later reported also from Northern Italy (Arrigoni 1990, 2012, Arrigoni et al. 2007). Furthermore, similar morphotypes were also found in Slovakia and the Czech Republic (Dostálek 1979). Works based on the "traditional" approach (e.g. Terpó 1960, Soó 1966, Terpó \& Amaral 1968, Bőhm 2007, 2010) have never questioned its status as a separate species; however, some sources (e.g. Király 2007) formulated explicit doubts on its status. The standpoint of Dostálek (1979) on the presence of similar types in the former Czechoslovakia was not supported by subsequent monographs neither in Slovakia (Peniašteková 1992) nor in the Czech Republic (Dostálek 2003). In Italy, Arrigoni (2012) reported several specimens revised by Terpó as P. magyarica, but this name has been treated synonymously for $P$. cordata Desvaux (1818: 152) in the national checklist (Conti et al. 2005). Nevertheless, four new species of Pyrus described recently from Italy confirm the above average diversity of the genus there (Marino et al. 2012).

After studying all accessible sources we concluded that confusions around P. magyarica are basically caused by the obscurity of type material. We attempted to get access to herbarium and/or living specimens, especially to original vouchers of Terpó. In this paper we review the evaluation of former records and formulate proposals for the future treatment of P. magyarica.

\section{Materials and Methods}

We revised the description of Pyrus magyarica and allied taxa following the Botanical Code (McNeill et al. 2012). We also considered every published records of the name, and tried to get access to every unpublished record and other sources, which could support the current treatment of the taxon. We checked all relevant Hungarian herbaria (BP, BPU, DE, acronyms follow Thiers 2013), where original material of the taxon was expected to be deposited. Additionally, the material of the herbarium of the University of Horticulture and Viticulture in Budapest, recently incorporated 


\section{Acknowledgements}

The authors owe to thank to Sándor Barabás (Corvinus University, Budapest) who looked for living material in the Soroksár Botanical Garden and to Ábel Beránek and Tibor Standovár for linguistic corrections.

\section{References}

Arrigoni, P.V. (1990) Flora e vegetazione della Macchia lucchese di Viareggio (Toscana). Webbia 44: 1-62. http://dx.doi.org/10.1080/00837792.1990.10670465

Arrigoni, P.V., Ferrettu, G. \& Padula, M. (2007) La flora della riserva di luoghi naturali “Orrido di Botri” (Bagni di Lucca, in Toscana). Parlatorea 9: 7-39.

Arrigoni, P.V. (2012) Miscellaneous notes about some taxa of the Italian flora. Webbia 67: 37-46. http://dx.doi.org/10.1080/00837792.2012.10670907

Bilz, M., Kell S.P., Maxted, N. \& Lansdown, R. (2011) European Red List of vascular plants. Publications Office of the European Union, Luxembourg, $130 \mathrm{pp}$.

Bőhm, É.I. (1998) A Pyrus magyarica Terpó és a Pyrus × karpatiana Terpó elkülönítő bélyegei a Pyrus pyraster Burgsd.-től. Kitaibelia 3: 109-111.

Bőhm, É.I. (2007) Fokozottan védett növényfajunk, a magyar vadkörte (Pyrus magyarica Terpó), valamint alakkörének kutatása Magyarországon. Tilia 13: 95-104.

Bőhm, É.I. (2010) Magyar vadkörte (Pyrus magyarica Terpó). Tilia 15: 149-157.

Burgsdorff, F.A.L. (1790): Anleitung zur sicheren Erziehung und zweckmässigen Anpflanzung der einheimischen und fremden Holzarten, Vol. 2. Berlin, 280 pp.

Conti, F., Abbate, G., Alessandrini, A. \& Blasi, C. (eds.) (2005) An annotated checklist of the Italian vascular flora. Ministero dell'Ambiente e della Tutela del Territorio. Direzione per la Protezione della Natura, Dipartimento di Biologia Vegetale; Università degli Studi di Roma "La Sapienza", Roma, 420 pp.

Desvaux, N.A. (1818) Observations sur les Plantes des Environs d'Angers. Paris, 188 pp.

Dostálek, J. (1979) Jsou na územi Ceskoslovenica reliktní hrusne (Pyrus) ze sekce Pashia? Preslia 51: 203-211.

Dostálek, J. (2003) Pyrus. In: Hejný, S. \& Slavíl, B. (eds.) Květena České Republiky, Vol. 3. Academia, Prague, pp. 464-470.

Király, G. (ed.) (2007) Red list of the vascular flora of Hungary. Private edition, Sopron, 73 pp.

Kurtto, A., Sennikov, A.N. \& Lampinen, R. (2013) Atlas Florae Europaeae. Distirbution of vascular plants in Europe, Vol. 16. Helsinki, The Committee for Mapping the Flora of Europea \& Societas Biologica Fennica Vanamo, 168 pp.

Koehne, E. (1890) Die Gattungen der Pomaceen. Gaertner, Berlin, 33 pp.

Marino, P., Castellano, G., Raimondo, F.M. \& Spadaro, V. (2012) Pyrus ciancioi (Rosaceae) a new species from Sicily. Plant Biosystems 146: 654-657.

http://dx.doi.org/10.1080/11263504.2012.700960

McNeill, J., Barrie, F.R., Buck, W.R., Demoulin, V., Greuter, W., Hawksworth, D.L., Herendeen, P.S., Knapp, S., Marhold, K., Prado, J., Prud'Homme, Van Reine, W.F., Smith, G.F., Wiersema, J.H. \& Turland, N.J. (2012) International Code of Nomenclature for algae, fungi, and plants (Melbourne Code) adopted by the Eighteenth International Botanical Congress Melbourne, Australia, July 2011. [Regnum Vegetabile 154]. Gantner, Ruggell, 240 pp.

Németh, F. (1989) Száras növények. In: Rakonczay Z.: Vörös könyv. Akadémiai Kiadó, Budapest, pp. 265-321.

Paganová, V. (2003) Taxonomic reliability of leaf and fruit morphological characteristics of the Pyrus L. taxa in Slovakia. Horticultural Science (Prague) 30(3): 98-107.

Peniašteková, M. (1992) Pyrus L. Hruška. In: Bertová, L. (ed.): Flóra Slovenska, IV/3. Veda, Bratislava, pp. 381-388.

Soó, R. (1966) A magyar flóra és vegetáció rendszertani-növényföldrajzi kézikönyve, Vol. 2. Akadémiai Kiadó, Budapest, 655 pp.

Terpó, A. (1960) Magyarország vadkörtéi (Pyri Hungariae). Kertészeti és Szölészeti Főiskola Évkönyve 11: 1-258.

Terpó, A. \& Amaral, F. (1968) Pyrus L. In: Tutin, T.G., Heywood, V.H., Burges, N.A., Moore, D.M., Valentine, D.H., Walters, S.M., Webb, D.A., Ball, P.W., Chater, A.O. \& Ferguson I.K. (eds.): Flora Europaea, Vol. 2. University Press, Cambridge, pp. 65-66.

Terpó, A. (1985) Studies on Taxonomy and Grouping of Pyrus Species. Feddes Repertorium 96: 73-87. http://dx.doi.org/10.1002/fedr.4910960114

Terpó, A. (1992) Pyrus taxa in Hungary, and their practical importance. Thaiszia : 41-57.

Thiers, B. [2013, continuously updated]. Index Herbariorum: A global directory of public herbaria and associated staff. New York Botanical Garden's Virtual Herbarium. http://sweetgum.nybg.org/ih/ (accessed: 10 October 2013) 